\title{
The democratisation of party leadership selection: The Portuguese experience
}

\begin{abstract}
In recent years, members of established political parties have received increased powers to select candidates and leaders. Several explanations have been advanced to account for this trend, focusing on the evolution of the political system, the characteristics of party systems or intra-party dynamics. The aim of this article is to examine the introduction of democratising reforms for leadership selection in Portuguese parties. Despite the high degree of centralisation and the low levels of internal participation, all governing parties have expanded members' rights during the last decade. The main findings suggest that party leaders have decided to change methods for leadership selection mainly for instrumental purposes in order to consolidate their internal power or gain electoral benefits. Moreover, this organisational transformation has had reduced effects on the internal party functioning. Regardless of these similarities, the data show that there are important differences between parties with regard to levels of participation and internal competition.
\end{abstract}

\section{INTRODUCTION}

Political parties in contemporary democracies have experienced important organisational changes in recent decades, notably towards internal democratisation (Bille 2001; Kittilson and Scarrow 2003). While leaders' election by

\section{KEYWORDS}

party leaders party change intra-party democracy leadership selection political parties Portugal 
party congress or by party national bodies continues to be the rule in most established democracies, in many European countries political elites have decided to change the internal rules for leadership selection.

The empowerment of party members for the selection of party leadership has not only occurred in northern countries - for example in Denmark, Finland, Belgium or Ireland - but it has recently been expanded also to southern Europe (Kenig 2009; Wauters 2010). Although the traditional indirect method of leadership selection is still clearly predominant, south European parties have recently undergone significant changes, especially in Greece (PASOK - Panhellenic Socialist Movement), Italy (Democrats of the Left - DS, now the Democratic Party) and Portugal (Bosco and Morlino 2007).

The Portuguese case deserves particular attention, as all major parties have decided to adopt this form of selection during the last decade. The Socialist Party (PS - Partido Socialista) was the first to introduce the direct election of party leaders in 1998. This organisational change was to remain an exception until the two parties of the right - the Social Democrats (PSD Partido Social Democrata) and the Social and Democratic Centre-Popular Party (CDS-PP - Centro Democrático e Social-Partido Popular) - recently decided to introduce the selection of party leadership by individual members.

This evolution appears quite surprising, as Portuguese parties have been characterised by a high degree of centralisation, especially with regard to the selection of party candidates and leaders and the elaboration of policy orientations (Freire 2001; Lobo 2003).

If we consider the inclusiveness versus exclusiveness continuum adopted by Rahat and Hazan (2001) to gauge the democratic character of party functioning, all governing parties display a low level of intra-party democracy, members' participation and openness of internal decisionmaking mechanisms. Overall, the main Portuguese political parties can be considered essentially as 'electoralist parties', characterised by the concentration of power in party executives, while party leaders have maintained a large degree of autonomy (Magone 2004; Jalali 2007). The increasing governmentalisation of the main parties and their entrenchment in the state have further enhanced the marginalisation of party members and the distance between grassroots and party elites (Lobo 2003; Lopes 2005). In this sense, it is even more puzzling that the adoption of every-member voting for leadership selection has taken place in a context of highly centralised political parties, low levels of intra-party democracy and an overwhelming elite control over party politics.

In this article, I analyse three specific cases of leadership selection experienced in Portugal during the last decade. While in the PS the democratisation of party leadership selection has been in place for quite a long period, in the case of the two parties of the right - PSD and CDS-PP - the change is very recent. The comparison between these experiences can shed more light on both the causes and consequences of the democratisation of leader selection, and on important aspects of party organisational change. This is even more valuable in the Portuguese case, as political parties have been resistant to transformations in party structures and internal functioning. Drawing on the democratising reforms undertaken in many political parties for leadership selection, the following section will point out some interpretations about the factors leading to the adoption of every-member voting. The third part will examine the Portuguese case, highlighting the 
differences and similarities between the right and the socialist experiences. In the subsequent section, I will consider some of the consequences of these reforms in the three parties, while in the conclusions I will discuss the main findings in comparison with similar cases across Western Europe, emphasising the contribution of this research to the study of contemporary political parties.

\section{THEORETICAL ARGUMENTS FOR THE DEMOCRATISATION OF PARTY LEADERSHIP SELECTION}

The literature on political parties offers several interpretations about the adoption of democratising reforms for leadership selection. Generally, party organisational change can stem from both endogenous and exogenous factors (Panebianco 1988; Harmel and Janda 1994). While the characteristics of the political system and the evolution of party systems may influence the rules for the selection of party leaders, party organisations usually enjoy a certain amount of autonomy and constitute an arena for struggle, especially in terms of decision-making powers. This means that the introduction of democratising reforms can be the consequence of different elements and a combination of both internal and external dynamics. Drawing on party literature, as well as on the experience undergone by West European parties, it is possible to point out several rationales for interpreting party primaries (Table 1). As Barnea and Hazan (2007) have noted, the different explanations for intra-party reforms can be distinguished between the political system level, the party system level and the party organisation level.

There are three distinct arguments related to the evolution of the political system with regard to the expansion of members' rights for leadership selection. These theories focus mainly on long-term transformations, such as the growing lack of legitimacy of political parties, the presidentialisation of politics and the increasing cognitive mobilisation of party members and voters. The fourth and fifth rationales are based on party system characteristics and interparty competition, while the 'cartel party' thesis is built on both external and internal arguments. Finally, there are also arguments that apply essentially to the internal functioning of political parties.

These alternative explanations of the adoption of democratising reforms are not, of course, mutually exclusive. In most cases, more than one argument is needed to interpret and understand why parties have decided to shift new powers to members.

The first interpretation of the adoption of the membership vote for choosing party leaders refers to the functional and organisational crisis of political parties in contemporary democratic polities. Several authors have argued that political parties have lost the capacity to attract party members and to foster grassroots mobilisation, failing to perform some of their traditional functions, such as promoting participation and articulating demands from civil society (Bartolini and Mair 2001; Schmitter 2001).

According to Ignazi et al. (2005), as parties have lost their capacity to distribute ideological incentives and have increasing difficulty retaining members' support through material benefits, they prefer to introduce procedural incentives in order to stimulate membership participation and to enhance party cohesion. Thus, every-member voting is seen as a necessary instrument to strengthen the linkage between parties and civil society, especially with a growing dissatisfaction - if not hostility - towards party organisations. To 


\begin{tabular}{|c|c|c|c|}
\hline $\begin{array}{l}\text { Arena/Level of } \\
\text { analysis }\end{array}$ & Approach & Rationale & Main potential effects \\
\hline \multirow[t]{3}{*}{ Political system } & Party crisis & $\begin{array}{l}\text { Increase legitimacy } \\
\text { Introduction of collec- } \\
\text { tive incentives }\end{array}$ & $\begin{array}{l}\text { Increasing satisfaction with } \\
\text { political parties (and democ- } \\
\text { racy) } \\
\text { Increasing participation }\end{array}$ \\
\hline & Presidentialisation & $\begin{array}{l}\text { Personalisation of } \\
\text { party leadership }\end{array}$ & Leader-oriented campaigns \\
\hline & $\begin{array}{l}\text { Cognitive } \\
\text { mobilisation }\end{array}$ & Intra-party democracy & $\begin{array}{l}\text { Empowerment of party } \\
\text { members }\end{array}$ \\
\hline \multirow[t]{2}{*}{ Party system } & Responsiveness & $\begin{array}{l}\text { Redefine party policy } \\
\text { vis-à-vis voters and } \\
\text { members }\end{array}$ & $\begin{array}{l}\text { Policy and programmatic } \\
\text { change }\end{array}$ \\
\hline & Party competition & $\begin{array}{l}\text { Increase party } \\
\text { performance }\end{array}$ & $\begin{array}{l}\text { Change of electoral strategy } \\
\text { Electoral success }\end{array}$ \\
\hline \multirow[t]{2}{*}{$\begin{array}{l}\text { Party } \\
\text { organisation }\end{array}$} & Cartel party & $\begin{array}{l}\text { More autonomy for } \\
\text { leadership's negotia- } \\
\text { tion } \\
\text { Neutralisation of } \\
\text { middle-rank activists }\end{array}$ & Demobilisation \\
\hline & Party fragmentation & $\begin{array}{l}\text { Increase cohesion } \\
\text { Avoid or limit party } \\
\text { conflicts and splits } \\
\text { Struggle for power } \\
\text { among party leaders }\end{array}$ & $\begin{array}{l}\text { Centralisation or increasing } \\
\text { intra-party competition } \\
\text { Conflicts over internal rules }\end{array}$ \\
\hline
\end{tabular}

Table 1: Approaches for analysing party leadership democratisation.

recover the crisis of political parties in contemporary society, which can to a great extent be interpreted as a crisis of their image within public opinion (Dalton and Weldon 2005), parties may consider the adoption of leadership selection reforms as a means to regenerate their legitimacy and their confidence among citizens.

This interpretation is also linked to another important transformation of political parties at the system level: that is, the empowerment of leaders within party organisations. Overall, varied reasons can account for this phenomenon: the transformations of mass political communication - especially in regard to campaign politics - the presidentialisation of executives and, last but not least, the weakening anchorage of party organisations (Poguntke and Webb 2005). In this sense, the democratisation of leadership's selection mirrors the internal distribution of power and the increasing personalisation of political parties. With a growing concentration of powers in the leaders' hands, party members become directly responsible for leadership choice.

According to some scholars, this trend can also be interpreted as a process of the 'Americanisation' of political parties in Western European democracies (Young and Cross 2002; Barnea and Hazan 2007). Yet, the process of 
democratisation may also play an important role in new democracies where party leaders displayed great prominence during the democratic transition (Van Biezen 2003).

Another important reason associated with the evolution of the political system focuses on the changing characteristics of party members and the electorate. During past decades citizens have acquired new competences, have increased their knowledge and have become less attached to political parties. According to several authors, they have also changed their attitudes, not only by displaying more criticism towards parties (Norris 1999; Dalton 2004), but also by supporting more direct forms of political participation in order to influence policy outcomes. This process has created favourable conditions for opening up party organisation and for the empowerment of party members. As a consequence, a growing normative concern related to members' participation and the transparency of internal party functioning has emerged in most contemporary societies (Harmel and Janda 1994; Kitschelt 2006; Valbruzzi 2005). This rationale is also linked to social capital theories, which stress the importance of high levels of mobilisation for increasing the quality of democracy.

The fourth and fifth arguments refer mainly to the party system level. Some authors have found that one of the main reasons to adopt direct leadership selection is the lack of representativeness of the party elites, especially the party in public office (Cross and Crysler 2009). From this point of view, the direct election of party leaders has two main objectives. On the one hand, it may make government action more cohesive and efficient, contributing to maximise the implementation of policies according to the party mandate: as several authors have noted (Hopkin 2001; Rahat 2008), this process can prompt a retrospective responsiveness, when party members are so dissatisfied with their leaders they decide to use their 'voice' in order to remove them from power. On the other hand, the direct participation of party members (and voters) may provide important feedback for party leaders that can increase the responsiveness of the party leadership and the congruence between the party action and voters' preferences, thus fostering a prospective responsiveness (Maravall 2008). In this case, democratisation would lead to the choice of moderate candidates who have better chances to appeal to the average voter, thus rejecting radical leaders with less chance of winning office.

This argument is strictly linked to more 'rational' motivations of party leaders whose interest in adopting the direct election stems from the need to enhance party electoral appeal among voters. In this sense, the democratisation of leadership selection is seen as an electoral asset with the aim of maximising party support and consolidating the position of party leaders. According to this rationale, this change often takes place after a major electoral setback, leading the leadership to try to mobilise new voters and attract new members. In other words, when the party is in opposition and wants to (re)gain voters' confidence and support, party leaders may decide to give the rank-and-file a greater say. Thus, the timing of the introduction of these organisational reforms is crucial in order to understand whether the motivations for reforms follow merely electoral considerations. In this sense, the change of leadership selection method is part of a strategic plan aiming at strengthening leaders' image and party electoral performance. The Italian case can be considered an example of the strategic use of party primaries, especially with regard to the leader's selection of the centre-left coalition for the 2006 election. The 
campaign by Romano Prodi was the first step of his electoral strategy that sought to enhance his popularity and improve the coalition's performance.

This example leads to the consideration of another aspect of the democratisation of leadership selection, one that brings the importance of the internal party arena to the fore. This focuses on the need to reduce internal conflicts, as they can endanger the electoral performance and bar parties' strategic and programmatic adaptation. The oft-used explanation for the expansion of democratisation reforms regarding leadership selection stems from Katz and Mair's hypothesis about the strategic calculus of party elites in introducing internal reforms for party leaders' selection (Katz and Mair 1995; Mair 1997). According to this rationale, the adoption of the one-member-one-vote $(\mathrm{OMOV})$ method is a way to reduce the power of party activists and middlerank members, while empowering individual participation and rights. By the same token, party leaders are easily able to control internal struggles and achieve stronger cohesion. The selection of party leadership would be just a way to legitimise the leader's orientations and to attribute more freedom of manoeuvre in regard to strategic and programmatic action. The 'cartel party' thesis considers the expansion of intra-party democracy as a means to disempower party activists and facilitate accommodation between parties at the elite level (Katz and Mair 2009). According to this interpretation, democratising reforms are a consequence of both external and internal factors. On the one hand, party elites need to negotiate with other actors of the party systems and they have to protect their position; on the other, they need to limit internal conflicts. Thus, this theory aims to bridge the gap between externally-based motivation and internal constraints.

This brief literature review would not be complete without taking into account an important aspect based on specific organisational dynamics. Party organisations can be seen as an arena of conflicts where the main actors contend for portions of power. As Panebianco (1988) stressed, democratising reforms are often an instrument through which challengers gain internal power and defeat the dominant coalition. From this perspective, while parties are usually seen as conservative organisations that tend to resist change, party leaders and factions play a crucial role in prompting organisational transformations (Wilson 1994). The dynamics and structure of intra-party bargaining is influenced by internal party rules, and these represent the first element incumbent leaders need to control in order to achieve their objectives.

Our argument is that the rationale for the adoption of democratising reforms in recent democracies is both an externally- and internally-driven process. On the one hand, party elites are pressured by electoral competition, and may use more inclusive leadership selection procedures to obtain benefits in the electoral arena; on the other, leaders can strengthen their position within the party by insulating themselves from critics or failures to achieve the main objectives. Both arguments are particularly important when we consider the role and the characteristics of political parties in the recent southern European democracies, where the electoral performance posits relevant constraints for party action and for regulating horizontal conflicts within the dominant coalition. Thus, in order to interpret the rationale of democratising reforms for leaders' selection, it is extremely important to investigate the 'instrumentality' of these changes, often used by party elites for their own desired outcome. In the sections that follow, I will explore this argument in regard to Portuguese political parties, underlining the marginal impact of these reforms in altering the main features of intra-party politics. 


\section{THE INTRODUCTION OF DEMOCRATISING REFORMS FOR PARTY LEADERSHIP SELECTION IN PORTUGUESE POLITICAL PARTIES}

Portuguese political parties have traditionally been characterised by a high level of centralisation, while leaders have displayed significant powers. To a large extent this is the consequence of being internally created parties with important organisational resources in the hands of the main leaders. They usually control the extra-parliamentary party - which is the most important face of party organisations - as the party in central office overshadows the legislative party (Van Biezen 2003). Party leaders also benefit from the fact that, with few exceptions, prime ministers have always been the effective leaders of their respective parties. Although formally selected by (and accountable to) party congresses, party leaders have a significant degree of autonomy in terms of intra-party dynamics, while cases of competition for party leadership were rare, especially when parties hold government positions. Mário Soares, the historic leader of the PS (1974-1986), and Freitas do Amaral, the CDS leader (1974-1982), dominated the internal party life of their respective parties, displaying very stable leaderships. While the leading role of party chair in the PS and in the CDS is evident, in the PSD party leaders have essentially been managers rather than uncontested decision-makers. However, during the PSD majority governments (1987-1995), Cavaco Silva was able to control the extra-parliamentary party from the executive, reducing the centrifugal tendencies (Lobo 2005).

One of the most important organisational transformations undergone by Portuguese political parties during the last decade relates to the adoption of party leader elections by party members. The PS was the first to introduce democratisation reforms in the late 1990s, while the two parties of the right adopted direct leadership selection only recently, between 2005 and 2006. ${ }^{1}$ In all these parties participation in the selection of the party leadership is limited to party members. ${ }^{2}$ In both the socialist and the parties of the right, the reform of leadership selection method stemmed from the party leaders' strategic calculation, which seeks to strengthen their position in the electoral arena or against internal opposition. The decision to adopt every-member voting was a conflictual issue in all parties. In this section, I will analyse how these parties undertook these reforms and the rationale behind these processes.

\section{THE INTRODUCTION OF DIRECT LEADERSHIP SELECTION IN THE SOCIALIST PARTY}

Although the introduction of direct leadership selection took place in 1998, the genesis of democratisation reforms in the PS dates back to the beginning of the 1990s. The background prompting the debate on leadership selection methods stemmed from the struggle for party leadership after Soares's withdrawal. The incumbent leader, Jorge Sampaio, proposed the adoption of everymember voting when Guterres challenged his leadership in 1992. ${ }^{3}$ The latter, who was firmly against this proposal, was able to gain control over the party and implemented an organisational change that failed to strengthen internal participation and to enhance legitimisation (Van Biezen 2003; Lisi 2009). This radical transformation of the party organisation was based on the abolishment of the congress and the introduction of a convention elected directly by party members. It was only after the success in the 1995 legislative elections that a favourable environment was mature enough for the adoption of direct
1. The Communist Party is an exception to the main organisational characteristics shared by governing parties In this case, the party leadership is selected by the Central Committee, which is the most important authority between congresses. This method has remained unchanged, although some critics have recently defended the introduction of democratising reforms. The Left Bloc (Bloco de Esquerda), a left-wing party formed in 1999, has adopted a more collegial leadership style.

2. In many cases members have to belong to the party for a certain length of time before being eligible to participate Unlike what happens in some other European parties, in none of the Portuguese parties is a voting fee required in order to participate.

3. See the motion advanced by Sampaio in the 1992 congress (Directas Já!). This proposal included the introduction of primaries for all public offices. See also Público 5 May 2006. 
leadership elections. Guterres was thus the first Portuguese party leader ever to be chosen by an every-member voting mechanism.

It is worth recalling the context in which the introduction of direct election came about in order to understand the rationale behind it. The prime minister was in a very good situation following his government's economic successes (entry in the European Monetary Union), the high degree of internal consensus through successful social policies (low rate of unemployment, introduction of a minimum wage) and also international prestige (organisation of Expo 1998) (Lobo and Magalhães 2004). In addition to these favourable external conditions, the socialist leader was experiencing a very positive moment with regard to the internal party life, as the party elite displayed a strong cohesion and fully supported the executive's policies.

These factors represented favourable conditions for the adoption of direct leadership selection methods. First, the electoral success led to the neutralisation of internal tensions and the distribution of selective incentives was widely used to control middle-rank elite and party activists. Second, access to power paved the way to the subordination of the extraparliamentary party to the party in government. Meetings of national party bodies and structures were increasingly sporadic, while the core executive deeply influenced the internal party life. Finally, Guterres decided to open up the leader's election when another major restructure of the party organisation took place. In 1998, the PS elite decided to restore the traditional party conventions and re-established the congress as the main deliberative body. However, the hierarchical structure based on the representative principle was now combined with the introduction of the direct election for party leader, thus accepting the organisational change proposed by Sampaio. In this sense, this reform was a compromise between those leaders defending a more conventional party structure, on the one hand, and those advocating the need to implement new linkages between party elites and members, on the other.

In this context, the first election for a leader of the party was a plebiscitary legitimisation of Guterres' leadership. Official data reported a 65 per cent turnout, with Guterres receiving almost 97 per cent of the members' votes (Table 2), and no other candidates contesting party leadership.

Despite the renewal of the socialist majority in 1999, the prime minister experienced increasing problems inside the government, deepening the tensions between the party in public office and the party in central office. This contributed towards demobilising party members, as is demonstrated by the fact that in the following direct election, which was held in 2001, the participation rate dropped to 43 per cent, although data on party members had not updated and must therefore be considered with caution. The fall in participation was probably also related to the lack of competition, as the party leader was the only candidate contesting the election.

Guterres resigned as prime minister after a governmental crisis prompted by defeat in the 2001 local elections. The socialists had to find a new leader to stand as candidate in the elections scheduled for March 2002. The way in which the new leader was selected reflects the limitations to the empowerment of party members within the PS. In fact, the main party leaders chose Ferro Rodrigues, a former minister in Guterres's governments and one of his closest collaborators, as the candidate for the 2002 elections. The new leader was presented to the voters in January, although no competition took place. In this sense, the internal campaign was simply an instrument 


\begin{tabular}{|c|c|c|c|c|c|c|c|}
\hline Leader & Year & $\begin{array}{l}\text { Number } \\
\text { of voters }\end{array}$ & Turnout & $\begin{array}{l}\text { Votes } \\
(\%)\end{array}$ & $\begin{array}{l}\text { Voters as } \\
\text { percentage } \\
\text { of support- } \\
\text { ers in } \\
\text { previous } \\
\text { election }\end{array}$ & $\begin{array}{l}\text { Competi- } \\
\text { tion }\end{array}$ & $\begin{array}{l}\text { Institutional } \\
\text { status }\end{array}$ \\
\hline Guterres & 1999 & 74,700 & 65 & 96.6 & 2.89 & No & Government \\
\hline Guterres & 2001 & 53,645 & 43 & 96.3 & 2.27 & No & Government \\
\hline $\begin{array}{l}\text { Ferro } \\
\text { Rodrigues }\end{array}$ & 2002 & $\begin{array}{c}10-15,000 \\
\text { approx. }\end{array}$ & 15 & 96.4 & $\begin{array}{r}0.50 \\
\text { approx. }\end{array}$ & No & Opposition \\
\hline Sócrates & 2004 & 36,182 & 48 & 80.1 & 1.76 & Yes & Opposition \\
\hline Sócrates & 2006 & 25,709 & 27 & 97.2 & 1.00 & No & Government \\
\hline Sócrates & 2009 & 25,331 & 36 & 96.4 & 0.99 & No & Government \\
\hline Average & - & 43,313 & 39 & 93.8 & 1.56 & - & - \\
\hline
\end{tabular}

Source: Party headquarters.

Table 2: The election of Socialist leaders.

to enhance internal legitimacy through the ratification by party members of a choice previously made by the party elite. Moreover, the campaign for party leadership was used to attract media attention and to reach voters in an effort to improve the candidate's image. Even had Ferro Rodrigues been one of the best-known socialist ministers and displayed a positive image to the electorate, the campaign for party leadership represented the first step of the electoral campaign, and it allowed the new leader to test the impact of his political message and to receive feedback from party supporters.

That this election was anything but competitive emerged for the request put forth by Ferro Rodrigues himself to call for a second election at the 13th congress, which took place in November 2002. On that occasion a challenger emerged, a middle-rank leader practically unknown by the majority of party members and the public. ${ }^{4}$ The result was not very different from the previous one, with the incumbent receiving more than 96 per cent of the votes, while the electoral turnout remained very low (at approximately 15 per cent). Thus, as with the previous leadership elections, members did not have any real alternative beyond the incumbent leader. The plebiscitary elections served simply to confirm the choice made by the party elite and to project an image of internal unity that could influence public opinion positively.

Ferro Rodrigues had difficulty consolidating his leadership, both because the party was in opposition and because several top leaders became involved in a scandal relating to allegations of child abuse. He resigned during the political crisis of 2004 - a crisis that stemmed from the resignation of Prime Minister Durão Barroso and the formation of a new government led by Santana Lopes paving the way to a new competition for the party leadership.

After more than two years in opposition and several events that upset the socialist elite, divisions within the party could no longer be ignored. Three candidates now stood for leadership of the party. The first was José Sócrates,
4. Paulo Penedos challenged for the leadership, receiving less than two per cent of the votes. 
5. This figure is much more reliable than the previous ones, as the enrolment files were updated during Ferro Rodrigues's leadership and new rules were introduced that regulated party membership. a former minister in Guterres's governments and one of the most popular leaders. He was well-known among the public due to a television programme in which the future prime minister and PSD leader, Pedro Santana Lopes, also participated. Sócrates belonged to the moderate wing of the party and was a strong supporter of Guterres. The second candidate was Manuel Alegre, one of the PS's founding leaders, who represented the left wing of the party. His was an unexpected candidacy, which emerged after the previous leader, Ferro Rodrigues, decided to endorse and support his own candidate. Finally, the third candidate was João Soares, Mário Soares's son, who was considered an outsider, notwithstanding some important support from within the party elite.

The three candidates were involved in a very competitive campaign in comparison to previous leadership contests. This competition caught members' interest, and participation increased to 48 per cent. ${ }^{5}$ Participation by party members was enhanced both by the competition between the three candidates and by the political climate, which was characterised by increasing discontent with the centre-right government, and with Santana Lopes in particular.

Sócrates was elected as the new party leader with a comfortable majority, gaining more than 80 per cent of the votes. Alegre only achieved 15 per cent, while Soares managed five per cent. Thus, the competition proved to be more formal than substantial, for with Sócrates there was a large consensus around the choice of new leader. Despite this, the direct election contributed towards improving the party's image and communicating its policies and proposals to both members and voters.

Following the PS's victory in the 2005 legislative election, the new leader was able to improve his internal support and to further enhance party cohesion. In this sense, the blurring of internal tendencies and the unanimity characterising the socialist elite during the first months of Sócrates's leadership led to the plebiscitary confirmation of the prime minister at the 2006 party congress. Sócrates was re-elected without any internal opposition and in an election with a very low turnout (27 per cent of party members), obtaining more than 97 per cent of the votes cast - the highest percentage obtained by any socialist leader since the introduction of direct leadership election. Party members confirmed his leadership some months before the 2009 elections in a campaign in which the prime minister was again the only candidate. This time he received more than 96 per cent of the vote in an election with the lowest participation rate in absolute terms. Overall, while in government, the direct election of PS leaders has assumed the character of plebiscitary elections, with no real competition and relatively low levels of participation.

\section{TOO LATE OR TOO EARLY? THE EXPERIENCE OF THE PARTIES OF THE RIGHT}

Unlike the PS, the right-wing parties have only recently introduced direct leadership elections. Another remarkable difference between the socialists and the parties of the right is that neither the PSD nor the CDS-PP has experienced significant organisational changes. In both parties, the reform of leadership selection has its roots in internal party conflicts. As Panebianco (1988) pointed out, democratising reforms can often be interpreted as an instrument for challengers to stand against the dominant coalition and gain internal power. The 
opposition status has accelerated centrifugal tendencies, as is shown by the fact that between 2005 and 2010 the new method of leader selection has been used on seven occasions. This section will examine the rationale underpinning the introduction of democratising reform, as well as the rules and practise of leadership election in right-wing parties.

\section{The Social Democratic Party (PSD)}

Although the PSD decided to adopt every-member voting for leadership selection in 2006, the debate over this organisational change originated during the mid-1990s. The first proposal aiming at introducing direct election of party bodies was proposed in 1992 by Luis Filipe Menezes, a well-known leader with a strong base in the Oporto district. ${ }^{6}$ Yet, this proposal was unable to raise supporters within the party elite, and was immediately rejected by party leader and Prime Minister Cavaco Silva.

After defeat in the 1995 election, the internal dispute over party leadership caused deep conflicts between the main party factions to emerge (Frain 1998). Santana Lopes decided to oppose the incumbent leader (Marcelo Rebelo de Sousa) during the 19th congress in 1996. One of the main suggestions he made for the renewal of the party's organisation was the introduction of direct elections for the main party bodies, while the incumbent leader's motion called for the introduction of party primaries only for party leaders at the regional level (distrital). As it became clear that the majority of the party elite supported Rebelo de Sousa's leadership campaign, Santana Lopes decided to withdraw, opening the way for the approval of party changes by adopting an OMOV system for the selection of leaders at the regional level.

Santana Lopes again proposed democratising reforms during the 23rd congress (2000). Yet, according to an opinion poll of party delegates, the majority of the party's elite did not support this expansion of members' rights (Expresso 26 February 2000). The approval of the organisational changes proposed by Santana Lopes would have eventually suspended the congress in order to introduce the new mechanism for party leadership selection. This was in fact a sign of the deep politicisation of the every-member voting mechanism, opposing Durão Barroso to his main challenger, Santana Lopes. The incumbent leader gained the proposal of party changes and was re-elected party leader. However, an increasing proportion of the party elite considered the introduction of direct leadership elections inevitable in the mid-term, which softened Santana Lopes's defeat.

The debate over the introduction of democratic reform through party leadership selection re-emerged after Santana Lopes's resignation in the wake of the 2005 legislative elections, which led to the election of a new party leader - Luís Marques Mendes - at the 27th congress (2005). Mendes decided to convene a party convention in order to approve the change to the statutes, namely the direct leadership election and the payment of party membership fees as a prerequisite for obtaining the right to vote. This proposal was to raise some tensions among local party leaders - particularly in the Oporto district - and it was openly opposed by the Social Democratic Youth (JSD - Juventude Social Democrata).

Some leaders proposed further enhancing internal democratisation by introducing party primaries for candidate selection and for all public office holders at both national and local level. As noted above, Menezes and Santana Lopes were two of the strongest supporters for this organisational change.
6. Menezes was Secretary of State in Cavaco Silva's government from 1991 to 1995 and has been mayor of Vila Nova de Gaia since 1998. 
7. This was an example of using party rules regulating membership recruitment as a way to make it more difficult for non-members to join and participate in the leadership contest.
Several proposals for changes to the party constitution were advanced, each differing with regard to which positions should be subject to such primaries.

The organisational reform approved in 2006 (at the 28th congress) had three main objectives: the first was to open and to democratise party organisation, the second was to make the party leadership more responsible while the third was intended to increase internal participation and mobilisation. The motion proposed by Marques Mendes also included the creation of a new party organ formed by experts and specialists who could offer advice to the party leader. This proposal sought to increase the leader's resources by creating a staff that would elaborate specific policies and to define party strategy. It was also a means to overcome internal opposition, especially from those who were against the introduction of premier primaries, as was the case with most of Durão Barroso's followers, for example. However, in the end only 20 per cent of party delegates opposed Marques Mendes's proposals for organisational changes, and the new leader was elected by an overwhelming majority (Table 3).

Despite the positive results obtained by the PSD at local and presidential elections, Mendes' leadership experienced huge domestic and external difficulties, as an environment of deep criticism emerged within the PSD following its defeat in 2007 to Lisbon council. Due to the poor performance of the PSD's candidate, Mendes decided to resign and to call for a new leadership election. This was the chance Menezes had been waiting for since 2005 to challenge the leadership using the OMOV system.

The campaign for the 2007 primaries was characterised by conflicts on rules about who had the right to vote, serving to deepen the tensions between the two candidates. Menezes argued that party members could pay their fees right up until the election day, while the incumbent leader stated that only those members who had already paid their membership fees should be entitled to vote. ${ }^{7}$

Both leaders were deeply concerned about the support they could gather at the local level. While Mendes benefited from the support of most local party leaders and structures, Menezes sought to enhance his position among public office holders. In this sense, although the internal struggle - thanks to the media - had a large impact on public opinion, the party campaign tended to take place more at the local level than at the national. The national party elite stood aside from the conflict, and many well-known figures refused to take a position publicly in favour of one or other candidate - the clearest example being Manuela Ferreira Leite, a minister in Durão Barroso's government.

Following his election to the position of party leader (with 54 per cent of the vote), Menezes failed completely to implement the renewal of the party programme and enhance the role of the PSD as the main opposition. According to opinion surveys, there was still a wide gap between the PSD and the PS, while the new leader was not able to improve his popularity and consolidate his leadership within the party. Internal criticism rose steadily and led Menezes to resign.

The field of leadership candidates to replace Menezes was eventually whittled down to three. The first serious candidate was Pedro Passos Coelho, a former leader of the JSD, who called for the PSD to adopt a more liberal position. Santana Lopes, who tried to use his populism to appeal to activists without actually outlining a programme, also threw his hat into the ring. The final serious candidate was Manuela Ferreira Leite, one of the most popular ministers in Durão Barroso's government, whose candidacy sought to combine the institutional image she constructed while in office (based on her credibility 


\begin{tabular}{|c|c|c|c|c|c|c|c|}
\hline Leader & Year & $\begin{array}{l}\text { Number } \\
\text { of voters }\end{array}$ & Turnout & $\begin{array}{l}\text { Votes } \\
(\%)\end{array}$ & $\begin{array}{l}\text { Voters as } \\
\text { percent- } \\
\text { age of } \\
\text { support- } \\
\text { ers in } \\
\text { previous } \\
\text { election }\end{array}$ & $\begin{array}{l}\text { Competi- } \\
\text { tion }\end{array}$ & $\begin{array}{l}\text { Institutional } \\
\text { status }\end{array}$ \\
\hline \multicolumn{8}{|l|}{ CDS-PP } \\
\hline $\begin{array}{l}\text { Ribeiro e } \\
\text { Castro }\end{array}$ & 2005 & 5037 & 14.3 & 93.7 & 1.21 & No & Opposition \\
\hline Paulo Portas & 2007 & 7531 & 21.9 & 74.6 & 1.81 & Yes & Opposition \\
\hline Paulo Portas & 2008 & 6358 & 31.4 & 95.1 & 1.53 & No & Opposition \\
\hline Average & - & 6308 & 22.5 & 87.8 & 1.52 & - & - \\
\hline \multicolumn{8}{|l|}{ PSD } \\
\hline $\begin{array}{l}\text { Marques } \\
\text { Mendes }\end{array}$ & 2006 & 20,649 & 37.2 & 90.9 & 1.26 & No & Opposition \\
\hline $\begin{array}{l}\text { Luís Filipe } \\
\text { Menezes }\end{array}$ & 2007 & 20,701 & 60.7 & 54.1 & 1.26 & Yes & Opposition \\
\hline $\begin{array}{l}\text { Manuela } \\
\text { Ferreira Leite }\end{array}$ & 2008 & 45,444 & 58.9 & 37.9 & 2.77 & Yes & Opposition \\
\hline $\begin{array}{l}\text { Pedro Passos } \\
\text { Coelho }\end{array}$ & 2010 & 51,737 & 66.2 & 61.2 & 3.12 & Yes & Opposition \\
\hline Average & - & 34,632 & 55.7 & 61.0 & 2.10 & - & - \\
\hline
\end{tabular}

Source: Party headquarters.

Table 3: The election of leaders in right parties.

following her implementation of fiscal containment measures when in office) with a defence of social policies.

Although the turnout remained at the same level as the previous election, the absolute number of voters increased significantly as a result of the registration of new voters. The competition between the candidates encouraged the participation of new (and old) party members. Ferreira Leite was elected with 37.9 per cent of the vote, with Passos Coelho obtaining 30 per cent. This victory was closer than had been suggested by the opinion polls that had given Ferreira Leite a clear lead. ${ }^{8}$ The closeness of the result highlighted the deep divisions that existed within the party, as can be seen by the composition of the main party bodies elected during the 31st congress - split between the three candidates - and by the choice of the new parliamentary leader, elected just by a thin majority (54 per cent).

It is worth noting that while the participation rate was lower than in previous elections, the number of voters substantially increased, mainly due to the difficulties in maintaining an accurate membership list. This was also the consequence of the high level of competitiveness in this contest. However,
8. A survey conducted two weeks before the elections gave Ferreira Leite 64 per cent of the vote (Correio da Manhã 17 May 2008). 
9. Pedro Castanheira Barros, a middle-rank activist, also stood the success of the new party leader was inevitably linked to electoral performance during 2009. Despite relatively favourable conditions, Ferreira Leite was unable to improve the party's performance in the legislative and local elections held during September and October, respectively. She also had difficulty managing her relationship with the media and was unable to increase her popularity, while her proposals were not fully supported by her party. Following the election defeats of 2009, several party leaders called for her to resign. Passos Coelho was the first to declare that he would stand for the party's leadership.

Some party leaders publicly criticised the method of choosing party leaders when it became clear that a new election would soon take place. Santana Lopes' was the main voice of dissent, and he called for an extraordinary party congress to be held to debate the rules. He claimed that the reforms had been bad for the party and that the traditional representative mode of selection allowed party activists to discuss and energise the party platform, which would have positive effects in terms of participation and internal cohesion.

His proposal divided the party elite, particularly with regard to the timing of the leadership election. According to Santana Lopes, the election should have taken place only after the debate on the rules governing the election. However, Passos Coelho argued that the election should take place before the debate. The national party's decision-making bodies accepted Santana Lopes's proposal and postponed the election until after the extraordinary congress. This decision gave other people time to declare their intention to stand. Paulo Rangel, a former leader of the parliamentary group, stepped up, as did José Pedro Aguiar-Branco, who had replaced Rangel as leader of the PSD's parliamentary group. ${ }^{9}$ The majority of party delegates rejected Santana Lopes' proposal in the 2010 congress, but the results showed the division within the party on this issue (244 votes against, 241 in favour and 92 abstentions). This decision paved the way for the election of Passos Coelho, who won more than 61 per cent of the vote to become the new leader of the PSD.

\section{Democratic and Social Centre-People's Party (CDS-PP)}

The elite of the CDS-PP have always given little consideration to organisational matters within the party, and organisational reforms have mostly been used as an instrument to demonstrate the renewal of the party leadership or as a sign of intra-party democracy in order to appeal to voters. It is interesting to note that the debate about the selection of party leadership in the party suddenly moved from a proposal aiming to reduce the inclusiveness of leaders' selection to the introduction of direct election by party members.

In fact, during the 17th congress (2000) the incumbent - Paulo Portas suggested the creation of a senate, composed largely of leading figures within the party, to be responsible for choosing the party's leader (Expresso 11 March 2000). Thus, unlike with the PSD, the CDS suggested restricting the electorate, and criticised the populism embraced by the two major parties. However, the proposal did not receive the support of the majority of the party elite, and the leader continued to be elected by party delegates.

The debate about how the party leader should be elected emerged again after defeat in the 2005 legislative elections. When Portas resigned, the struggle for a new party leader resulted in Telmo Correia, a Portas supporter, facing José Ribeiro e Castro, a member of the European Parliament, who was able to gather a significant amount of support from critics of Portas's leadership. 
Surprisingly, 55 per cent of the party's delegates chose Ribeiro e Castro to lead them. However, even after his election at the party congress, Ribeiro e Castro was unable to overcome the divisions within the party.

One of his first actions was to introduce direct leadership elections. The opposition within the party elite argued against this proposal, defending the collective decision-making processes. Ribeiro e Castro had to approve a temporary change to the party's statutes that did not allow for the direct election of the party leader. According to the CDS-PP constitution, congress is the body responsible for all changes, so only congress could introduce everymember voting.

As with the PSD, the reform of selection methods was linked to the challenges the leadership had to face. In particular, internal fragmentation and divisions within the party elite were major concerns for the new leadership. In this sense, the democratisation of the party leadership selection process was seen as a means to overcome internal party conflicts and consolidate the new leadership.

The first time the CDS-PP's leader was elected by the party's members was in May 2005, and the only candidate was Ribeiro e Castro..$^{10}$ This organisational change sought to legitimise the new leader, thus strengthening the party's internal cohesion and limiting internal conflicts. It was also intended to mobilise the party membership in preparation for the local elections of October 2005. However, this change did not bring any benefit to the party in the short term, as the lack of internal competition for the leadership failed to attract new voters, while the party's supporters did not consider intra-party democracy to be a priority.

The second act took place in 2007 when Paulo Portas decided to challenge the party leader for the leadership. This time Ribeiro e Castro opposed the decision to choose the party leader through the OMOV mechanism, claiming a lack of respect for procedural rules. The problems around formal aspects were to result in legal challenges that involved all of the party's main institutions. After an internal struggle between the two opposing factions, which was echoed in public opinion, the party's national council approve the holding of an election for the leadership of the party, which Portas won with more than 74 per cent of the vote. Ribeiro e Castro criticised the way Portas had won.

Portas did not represent a clear change in party leadership. His commitment was to enhance the CDS-PP's appeal by reshaping the policy agenda. His main goal was to elaborate a new programme that was based on both traditional law and order policies and on such 'new politics' as the environment, social responsibility and quality of life. The defence of social policies was another priority for the new leadership, which it hoped to achieve by combining improvements in working conditions with protection of family. ${ }^{11}$ However, this policy renewal did not clearly emerge during the 2009 elections, while the leadership's popularity has remained closely linked to the performance of the main centre-right party.

Portas decided to anticipate both the election and the congress in order to avoid the emergence of an internal opposition candidate and to strengthen party cohesion for the series of elections in 2009. In December 2008 he was re-elected with 95.1 per cent of the votes. Although the turnout was higher than in the previous primary (31.4 per cent) - due to the clean-up of the party's membership list, which has substantially reduced the number of members eligible to vote - the absolute number of voters indicates that the party's grassroots are demobilising. Moreover, the weak institutionalisation
10. It is worth noting that direct election was not introduced into the party's statutes: it was considered to be a temporary measure.

11. See also the motion Um partido com soluções, prepared for the 23 rd congress of January 2009 
12. Data from internal referenda show the stability of turnout rates. The CDS-PP called for a referendum in 1992, in which 26 per cent of party members participated. Turnout in the socialist referendum in 1982 was 30 per cent.

13. Turnout is measured at the level of the freguesia (parish) (PSD), the constituency (CDS-PP) or provinces (PS). Competitiveness is measured as the difference between the first and second candidate. Thus: the smaller the difference the greater the degree of competition. When there are more than three candidates, we consider the difference between the two highest scores. The elections selected in this study are the only competitive ones for which data are available. of the direct leadership election process was reflected in the proposal by the party's youth section (Juventude Popular) during the 23rd congress in January 2009 to reintroduce the old-style party convention.

\section{THE EFFECTS OF DIRECT LEADERSHIP SELECTION: LESSONS FROM THE PORTUGUESE EXPERIENCE}

When dealing with the effects of the introduction of direct leadership selection we need to consider both internal and external consequences. The first dimension focuses on the increase in party membership and internal participation and the internal distribution of power; the second aspect centres on the leadership's ideological orientation and the personalisation of party politics.

Several authors have stressed that the introduction of party primaries should enhance both party membership and internal participation (Carty and Blake 1999; Pennings and Hazan 2001). Although in the Portuguese case there are virtually no data on party activism, and figures on party membership and internal participation are highly unreliable, the evidence from participation in the election of party leaders shows that the level of mobilisation varies greatly, ranging from 15 to 65 per cent.

On average, the PSD displays the highest rate of participation (55.7 per cent), while members of the CDS-PP are less likely to participate (22.5 per cent). The PS falls between these two (39 per cent). These figures are not significantly different from data on internal participation before the reform of leadership selection methods. ${ }^{12}$ Overall, the Portuguese experience shows that only a small fraction of the parties' supporters actually participates in these contests.

The main difficulty in assessing patterns of variation with regard to internal participation in leadership elections stems from the unreliability of membership figures provided by the parties. One of the main consequences of direct leadership selection is that the parties' estimates of their own membership have become more accurate because the reform has compelled the party elites to define the status of each member and to maintain more rigorous control of membership data. In particular, frequent and competitive leadership elections imply tight control of membership figures, but when party membership is not updated, turnout figures are likely to be inflated and it becomes difficult to make comparison across parties. Despite this, important differences between parties still exist, and this is a problem that must be addressed beyond the bias and imperfection of membership figures.

Participation in leadership selection may depend on several factors, including the different territorial traditions of political participation, the party's electoral strength, the level of competitiveness between parties, and the sociodemographic characteristics of the party's supporters. At the aggregate level, we observe a relative strong association between the competitiveness of the contests and the level of internal participation. ${ }^{13}$ The experience of the PS - the one with a longer tradition as far as direct leadership elections are concerned shows that competitive races are more likely to mobilise a greater number of party members, while 'coronations' are generally associated with demobilisation dynamics. Despite the high level of member participation in the first two elections, it must be noted that in 2004 - after the membership files had been updated - competition between three candidates raised the level of turnout (see Table 2). In this case every-member voting and leadership competition stimulated political participation, increasing party member mobilisation. 
However, the experience of the parties of the right suggests that when competition is just a struggle between top leaders, the effect on party mobilisation is the opposite, since a strong competition is associated with low participation. While in the case of the PS there is a positive relationship between the level of competition and turnout rates, for both the right-wing parties the relationship is stronger and, most strikingly, it is negative. ${ }^{14}$ This means that high turnout rates are associated with a wider gap between the two main contenders.

For example, in the 2007 CDS-PP elections, Portas's ability to mobilise his supporters increased the overall level of participation, while the local party sections where the challenger obtained his best scores were characterised by low turnout rates. The PSD shows the same pattern in respect of the 2008 and 2010 elections. Despite the higher rate of turnout compared to the CDS-PP, it is remarkable that the slope is almost the same (Figure 1). For both parties of the right, this preliminary analysis seems to suggest turnout depends to a great extent on the ability of the candidate to mobilise and generate support at the local level, rather than on the degree of competitiveness.

The second dimension considers the impact of direct leadership elections on the internal distribution of power. In both the PSD and the CDS-PP, the access of members to party organisation often takes place through clientelistic practices, particularly where party notables are able to control local structures and the recruitment of new members (Jalali 2007). While national party bodies usually disregard party organisation and members, local bosses can easily manipulate local party organs and the access members enjoy. In this sense, the introduction of direct leadership elections may lead to significant changes in the internal distribution of power, as it may enhance the centralisation and the concentration of power in the national party elite and reduce the importance of territorial cleavages (Corkill 1995).

As has been shown, the introduction of party primaries has triggered many conflicts within the party leadership in regard to the rules regulating the electorate. As the main Portuguese parties (especially the PSD) have been characterised by a high level of 'stratarchy' ${ }^{15}$ that bestows significant autonomy upon the local level (Jalali 2006), the introduction of OMOV may change the internal distribution of power, as party leaders can control directly members' participation.

In this respect, while for the PS the reform has enhanced the degree of centralisation without substantially altering the internal distribution of power (Lisi 2006: 390), the evidence from the PSD experience thus far has been mixed: Menezes's election seemed to show that local leaders have retained significant powers. However, several observers have suggested that in the 2008 elections, the role played by local leaders decreased, and that their influence on the selection of the party leader dwindled due to a lack of correspondence between the support of local leaders for each of the three candidates and the final result.

The third aspect worth highlighting relates to the ideological dimension. Have parties become more responsive towards members or their electoral bases? Several authors have argued that different selectorates imply the selection of different candidates in terms of policy orientation, and that democratising reforms are also an instrument for bypassing the parliamentary party's lack of representativeness (Carty and Blake 1999; LeDuc 2001; Cross and Crysler 2009). According to this hypothesis, party leaders should present moderate stances in order to appeal to the average voter, rather than reflecting members' preferences. Thus, by entitling party members to select the party
14. The correlation coefficients between turnout and competitiveness are 0.291 and 0.269 for the PSD (2008 and 2010, respectively) and 0.335 for the CDS-PP in the 2007 elections. All correlations are statistically significant at the 0.01 level (2-tailed). For the 2004 PS election, the correlation at the district level is -0.257 but it fails to be significant $(N=22)$. For better intuitive interpretation, the signs of competitiveness in Figure 1 have been changed.

15 . The concept of 'stratarchy' was originally applied to the analysis of political parties by Eldersveld (1964) in order to describe a situation where national and local party structures are independent of each other and are characterised by a functional differentiation. 


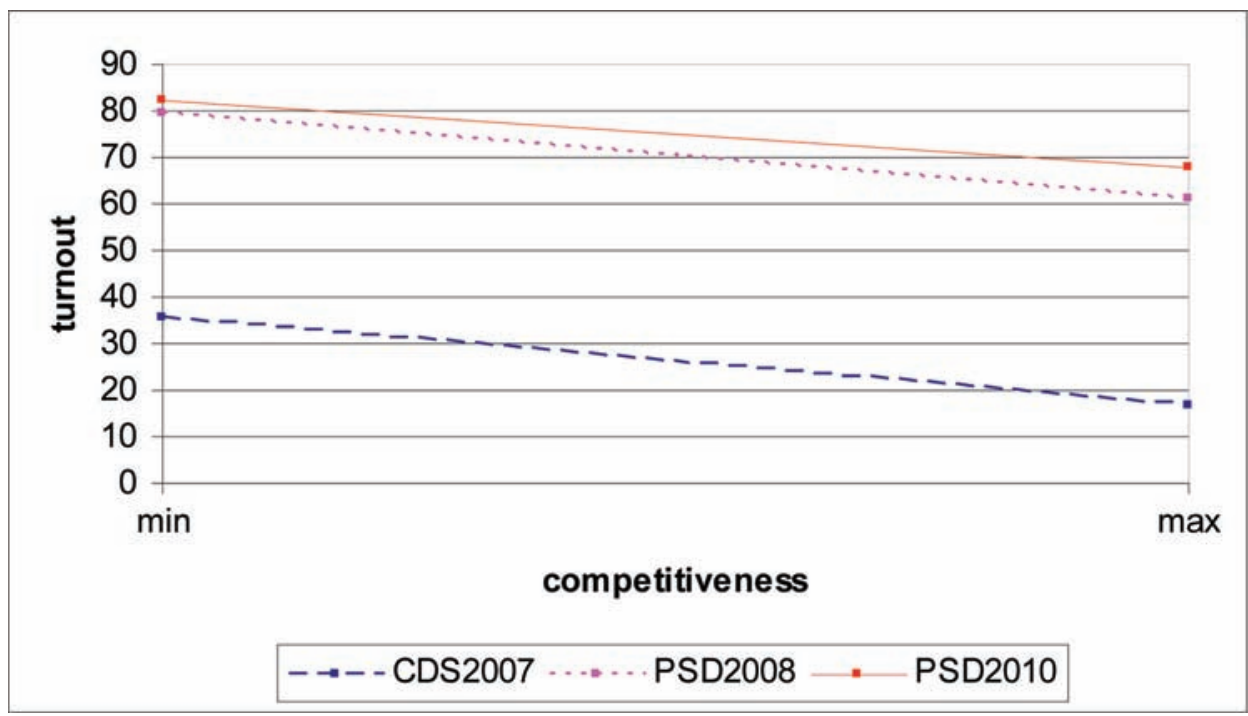

Source: Party headquarters.

Note: CDS-PP ( $N=151) ;$ PSD 2008 ( $N=328) ;$ PSD 2010 ( $N=329)$.

Figure 1: Turnout and competitiveness for leader elections of right parties.

leader it is easier to neutralise party activists and increase the responsiveness of parties towards the average voter.

Although this hypothesis may find some support in the experience of the British Labour Party (Hopkin 2001), it is hard to apply it to parties in southern Europe and, in particular, to Portuguese parties. In the PS, the front-runner has always displayed a moderate orientation that was overwhelmingly supported by both the party elite and its members. The PS favours a centrist strategy, and

\begin{tabular}{lccccccc}
\hline Leader & \multicolumn{3}{c}{ Participation } & \multicolumn{3}{c}{ Competitiveness } \\
\hline & $\begin{array}{l}\text { Mean } \\
(\mathbf{\%})\end{array}$ & $\begin{array}{l}\text { Std. } \\
\text { dev. }\end{array}$ & $\begin{array}{l}\text { Min-Max } \\
\mathbf{( \% )}\end{array}$ & $\begin{array}{l}\text { Mean } \\
(\mathbf{\%})\end{array}$ & Std. dev. & $\begin{array}{l}\text { Min-Max } \\
(\mathbf{\%})\end{array}$ & $(\mathrm{N})$ \\
\hline CDS-PP & & & & & & & \\
Ribeiro e Castro & 14.3 & 9.14 & $4.0-39.0$ & - & - & - & $(20)$ \\
Paulo Portas & 21.9 & 15.0 & $3.8-85.1$ & 54.2 & 26.6 & $0-100$ & $(151)$ \\
Paulo Portas & 31.4 & 13.7 & $12.7-68.0$ & - & - & - & $(20)$ \\
PSD & & & & & & & \\
Manuela Ferreira Leite & 58.9 & 15.5 & $3.45-100$ & 32.1 & 24.6 & $0-100$ & $(328)$ \\
Pedro Passos Coelho & 66.2 & 15.5 & $3.85-100$ & 44.3 & 28.2 & $0-100$ & $(329)$ \\
\hline
\end{tabular}

Source: Party headquarters.

Table 4: Participation and competition in right parties. 
left-wing candidates have always run as outsiders. Similarly, both the leaders of the PSD and the CDS-PP have shown a great congruence with their respective electoral bases, and no deep programmatic or ideological changes have taken place since the introduction of the direct election of party leaders.

The fourth aspect focuses on the diminishing role of political parties and the strengthening of candidate- and premier-centred politics. One of the consequences emphasised by political observers is that the adoption of party primaries will increase the personalisation of political parties (Seyd 1999; Young and Cross 2002).

Have democratising reforms weakened party organisations to the detriment of leaders, thus enhancing the personalisation of politics? To what extent will these reforms lead to the importation of some characteristics of American-style primaries in the Portuguese case?

Since the 2004 election of the PS leader, internal party campaigns have attracted widespread attention from the mass media and have been organised as electoral campaigns with a campaign staff and external consultants, raising the costs normally associated with internal elections. ${ }^{16}$

In many cases, the election of party leaders - as well as party conventions has become simply the 'coronation' of party leaders, while the traditional party meetings have to a large extent lost their drama and their importance in terms of deliberative gatherings. This fact suggests that the direct election of party leaders aims essentially at improving the image of the parties through media coverage. Thus, the mass media has played a fundamental role by contributing both to informing party members and to influencing voters and public opinion. This phenomenon also has an important impact on the functions developed by party organisations and local structures. As the link between party leaders and members is now mediatised - rather than mediated by party structures - leaders are directly accountable to party sympathisers, further 'hollowing-out' the traditional functions developed through party organisation.

\section{CONCLUSIONS}

The introduction of direct leadership selection represents one of the major organisational changes of Portuguese parties during the last decade.

What are the main forces that have led to this transformation? Overall, the three cases analysed in this study show that leadership selection reform is closely linked to internal party struggles and to pressures from the party system. Rather than leading to a radical change through the empowerment of party members, the democratisation of leadership selection is essentially a function of the strategic calculus of the party elite. In the case of the PS, this reform mainly had internal roots and was the effect of a process of elite negotiation with regard to the change of the overall party organisational structure. However, both the PSD and the CDS-PP have used direct elections in a period of leadership transition while they were in opposition, aiming to strengthen the legitimacy of the party leaders and improve the party's popularity.

Both right-wing parties decided to implement an organisational change after the 2005 election defeat that stimulated internal rivalries and resulted in high leadership turnover. In this sense, the struggle for party leadership seems to be the most important factor in favouring the adoption of direct election, confirming Panebianco's hypothesis that democratising reforms are essentially a 'Trojan horse' for enforcing a change of the dominant coalition.
16. All of the main Portuguese newspapers conducted opinion polls during the 2004 PS and the 2008 and 2010 PSD leadership elections, and gave the contests wide coverage. All of the party leaders formed ad hoc teams for the organisation of internal campaigns, while in the PSD external services were important for the campaigns of Luís Filipe Menezes in 2007 (Expresso 8 September 2007) and Passos Coelho in 2010. 
At the same time, this change seeks to increase support among voters and to increase electoral gains. The importance of isomorphic processes, that is, the 'contagion effect' the socialist experience has projected on the parties of the right - especially after the 2004 elections - should also be noted.

This finding is also supported by similar experiences across Europe, for example, in Spain and Italy. First, the Spanish Socialist Party (PSOE - Partido Socialista Obrero Español) decided to introduce the selection of the candidate for prime minister by party members in 1998 after the PP's victory two years earlier, while in Italy the centre-left parties decided to implement the selection of the coalition leader by party sympathisers in 2005, just months before the legislative elections. Second, in both cases the introduction of party primaries was an important asset to exploit both in the electoral arena, where it can be used to appeal to new supporters, and within the party organisation, where it can be used to defeat the internal opposition and enhance the legitimisation of the new leadership. The cases of PSOE, the Italian Democratic Left (DS Democratici di Sinistra) or PASOK in Greece confirm that the introduction of every-member voting essentially seeks to strengthen the electoral appeal of the party both internally and externally.

Beyond this common aspect, it is worth noting there are important differences between parties, especially with regard to levels of participation and competitiveness. These two dimensions are closely related, and this relationship emerges clearly for leadership elections in the PSD. However, the higher turnout rate of this party seems to be due also to the importance of local politics in mobilising party members. On the other hand, the extremely low levels of participation within the CDS-PP mirror its weak social roots and the difficulty it has in establishing organisational structures within civil society. Thus, in order to explain this variance it is also essential to take into account the legacy of party organisations, namely their 'genetic' model and its development.

Differences across parties also emerge in terms of competitiveness. In this case, it seems the main distinction is between incumbent parties and opposition parties. During the last decade the PS has been the main governing party in Portugal, with the exception of the brief right-wing coalition government between 2002 and 2004. This is also the party with the lowest level of competitiveness. The only exception concerns Ferro Rodrigues's leadership, which can be explained by the electoral and political context in which it took place. In the remaining cases, parties in opposition have always displayed a higher level of competitiveness.

There are, of course, other factors that contribute towards an explanation for the differences across parties. In particular, the traditionally high factionalism of the PSD and the importance of (potential) conflicts between the centre and periphery are also important elements accounting for the higher levels of competition within the party elite as opposed to both the PS and the CDS-PP.

Overall, the Portuguese experience suggests that this reform has not had a significant impact on party politics. The main governing parties have not used leadership campaigns to attract new members, and there has been little mobilisation of supporters during these contexts. Moreover, the strategic use of democratisation reform has been accompanied by a lack of internal debate among party members and by limited consequences for members' powers and internal participation. Without any real effect on the internal functioning of the parties, political leaders have thus found it an easy way to increase their power, while feeding the participatory and democratic myth. 
Although party leaders may strengthen their positions vis-à-vis party activists by reducing the decision-making capacity of collective party bodies, it is worth remembering that this is not a new trend in Portuguese parties, and that party organisations may still have important roles. As demonstrated by the PSD experience, local politics, membership dynamics and conflicts on internal rules are important elements that may limit the action of party leaders. In other words, it seems implausible that these reforms could lead, as in the United States, to a weakening of the role played by party organisations and to a reduction of political parties to 'empty vessels' (Katz 1990).

Party politics in Portugal - and more generally in Western Europe - is still well entrenched, and no internal reforms will change this in the foreseeable future, unless radical changes take place. Thus, contrary to the findings of LeDuc (2001) regarding the effects of the democratisation of party leadership selection in Britain, Canada and the United States, the Portuguese experience suggests that these reforms may not imply - at least in the short term - any loss of party control over the election of leaderships and, more generally, the irrelevance of party organisations.

\section{REFERENCES}

Barnea, S. and Hazan, R. Y. (2007), 'Reforming candidate selection methods', Party Politics 13 (3): 375-94.

Bartolini, S. and Mair, P. (2001), 'Challenges to contemporary political parties', in Diamond, L. and Gunther, R. (eds), Political parties and democracy, Baltimore, MD: The Johns Hopkins University Press, pp. 327-43.

Bille, L. (2001), 'Democratizing a democratic procedure: Myth or reality?', Party Politics 7 (3): 363-80.

Bosco, A. and Morlino, L. (eds) (2007), Party changes in southern Europe, London: Routledge.

Carty, R. K. and Blake, D. E. (1999), 'The adoption of membership votes for choosing party leaders', Party Politics 5 (2): 211-24.

Corkill, D. (1995), 'Party factionalism and democratization in Portugal', in Gillespie, R., Waller, M. and Nieto, L. L. (eds), Factional politics and democratization, London: Frank Cass, pp. 65-76.

Correio da Manhã, 17 May 2008

Cross, W. and Crysler, Y. (2009), 'Grassroots participation and party leadership selection: Examining the British and Canadian cases', in De Bardeleben, J. and Pammett, J. H. (eds), Activating the citizen: Dilemmas of participation in Europe and Canada, Basingtoke: Palgrave, pp. 173-93.

Dalton, R. J. (2004), Democratic challenges, democratic choices, Oxford: Oxford University Press.

Dalton, R. J. and Weldon, S. A. (2005), 'Public images of political parties: A necessary evil?', West European Politics 28 (5): 931-51.

Eldersveld, S. J. (1964), Political parties: A behavioral analysis. Chicago, IL: Rand McNally.

Expresso, 8 September 2007.

11 March 2000. 26 February 2000.

Frain, M. (1998), PPD/PSD e a consolidação do regime democrático, Lisbon: Notícias.

Freire, A. (ed.) (2001), Recrutamento parlamentar: Os deputados portugueses da Constituinte à VIII Legislatura, Lisbon: STAPE. 
Harmel, R. and Janda. K. (1994), 'An integrated theory of party goals and party change', Journal of Theoretical Politics 6 (3): 259-87.

Hopkin, J. (2001), 'Bringing the members back in?', Party Politics 7 (3): 343-61.

Ignazi, P., Farrell, D. M. and Römmele, A. (2005), 'The prevalence of linkage by reward in contemporary parties', in Römmele, A., Farrell, D. M. and Ignazi, P. (eds), Political parties and political systems: The concept of linkage revisited, Westport, CT: Praeger, pp. 17-35.

Jalali, C. (2007), Partidos e democracia em Portugal 1974-2005, Lisbon: Imprensa de Ciências Sociais.

— (2006), 'The woes of being in opposition: The PSD since 1995', South European Society \& Politics 11 (3-4): 359-79.

Katz, R. S. (1990), 'Party as linkage: A vestigial function?', European Journal of Political Research 18 (1): 143-61.

Katz, R. S. and Mair, P. (2009) 'The cartel party thesis: A restatement', Perspectives on Politics 7 (4): 753-66.

- (1995), 'Changing models of party organization and party democracy: The emergence of the cartel party', Party Politics 1 (1): 5-28.

Kenig, O. (2009), 'Democratization of party leadership selection: Do wider selectorates produce more competitive contests?', Electoral Studies 28 (2): 240-7.

Kitschelt, H. (2006), 'Movement parties', in Katz, R. S. and Crotty, W. J. (eds), Handbook of party politics, London: Sage, pp. 238-90.

Kittilson, M.C. and Scarrow, S. E., (2003), 'Political parties and the rhetoric and realities of democratization', in Cain, B. E., Dalton R. J. and Scarrow S. E. (eds), Democracy transformed? Expanding political opportunities in advanced industrial democracies, Oxford: Oxford University Press, pp. 59-80.

LeDuc, L. (2001), 'Democratizing party leadership selection', Party Politics 7 (3): $323-41$.

Lisi, M. (2009), A arte de ser indispensável: Líder e organização no Partido Socialista' Português, Lisbon: Imprensa de Ciências Sociais.

_ (2006), 'The importance of winning office: The PS and the struggle for power', South European Society \& Politics 11 (3-4): 381-97.

Lobo, M. C. (2005), Governar em democracia, Lisbon: Imprensa de Ciências Sociais.

— (2003), 'A elite partidária em Portugal, 1976-2002', in Pinto, A. C. and Freire, A. (eds), Elites, sociedade e mudança política, Lisbon: Celta, pp. 249-75.

Lobo, M. C. and Magalhães, P. (2004), 'The Portuguese Socialists and the third way', in Bonoli, G. and Powell, M. (eds), Social democratic party politics in contemporary Europe, London: Routledge, pp. 83-101.

Lopes, F. F. (2005), Os partidos politicos, Oeiras: Celta.

Magone, J. M. (2004), The developing place of Portugal in the European Union, New Brunswick, NJ: Transaction.

Mair, P. (1997), Party system change: Approaches and interpretations, Oxford: Clarendon Press.

Maravall, J. M. (2008) 'The political consequences of internal party democracy', in Maravall, J. M. and Sánchez-Cuenca, I. (eds.), Controlling governments: Voters, institutions and accountability, Cambridge: Cambridge University Press, pp. 157-201.

Norris, P. (ed.) (1999), Critical citizens, Oxford: Oxford University Press.

Panebianco, A. (1988), Political parties: Organization and power, Oxford: Oxford University Press. 
Pennings, P. and Hazan, R. Y. (2001), 'Democratizing candidate selection', Party Politics 7 (3): 267-75.

Poguntke, T. and Webb, P. (eds) (2005), The presidentialization of politics, Oxford: Oxford University Press.

Público, 5 May 2006

Rahat, G. (2008), Which candidate selection method is more democratic?, Center for the Study of Democracy, Irvine, CA: University of California.

Rahat, G. and Hazan, R. Y. (2001), 'Candidate selection methods', Party Politics 7 (3): 297-322.

Schmitter, P. C. (2001), 'Parties are not what they once were', in Diamond, L. and Gunther, R. (eds), Political parties and democracy, Baltimore, MD: The Johns Hopkins University Press, pp. 67-89.

Seyd, P. (1999), 'New parties/new politics', Party Politics 5 (3): 383-405.

Valbruzzi, M. (2005), Primarie: Partecipazione e leadership, Bologna: Bononia University Press.

Van Biezen, I. (2003), Political parties in new democracies: Party organization in southern and east-central Europe, London: Palgrave Macmillan.

Wauters, B. (2010), 'Explaining participation in intra-party elections: Evidence from Belgian political parties', Party Politics 16 (2): 237-59.

Wilson, F. L. (1994), 'The sources of party change: The social democratic parties of Britain, France, Germany, and Spain', in Lawson, K. (ed.), How political parties work, Westport, CT: Praeger.

Young, L. and Cross, W. (2002), 'The rise of plebiscitary democracy in Canadian political parties', Party Politics 8 (6): 673-99.

\section{SUGGESTED CITATION}

Lisi, M. (2010), 'The democratisation of party leadership selection: The Portuguese experience', Portuguese Journal of Social Science 9: 2, pp. 127-149, doi: 10.1386/pjss.9.2.127_1

\section{CONTRIBUTOR DETAILS}

Marco Lisi is a post-doctoral researcher at the Institute of Social Science at the University of Lisbon and a lecturer in political science at the New University of Lisbon. He has published several articles on political parties and political behaviour in such journals as South European Society and Politics, West European Politics and Análise Social. He also published the book A arte de ser indispensável: Líder e organização no Partido Socialista português, Imprensa de Ciências Sociais, 2009.

Contact: Instituto de Ciências Sociais-Universidade de Lisboa (ICS-UL), Av. Aníbal de Bettencourt, 9, 1600-189 Lisboa, Portugal.

Email: marco.lisi@ics.ul.pt 


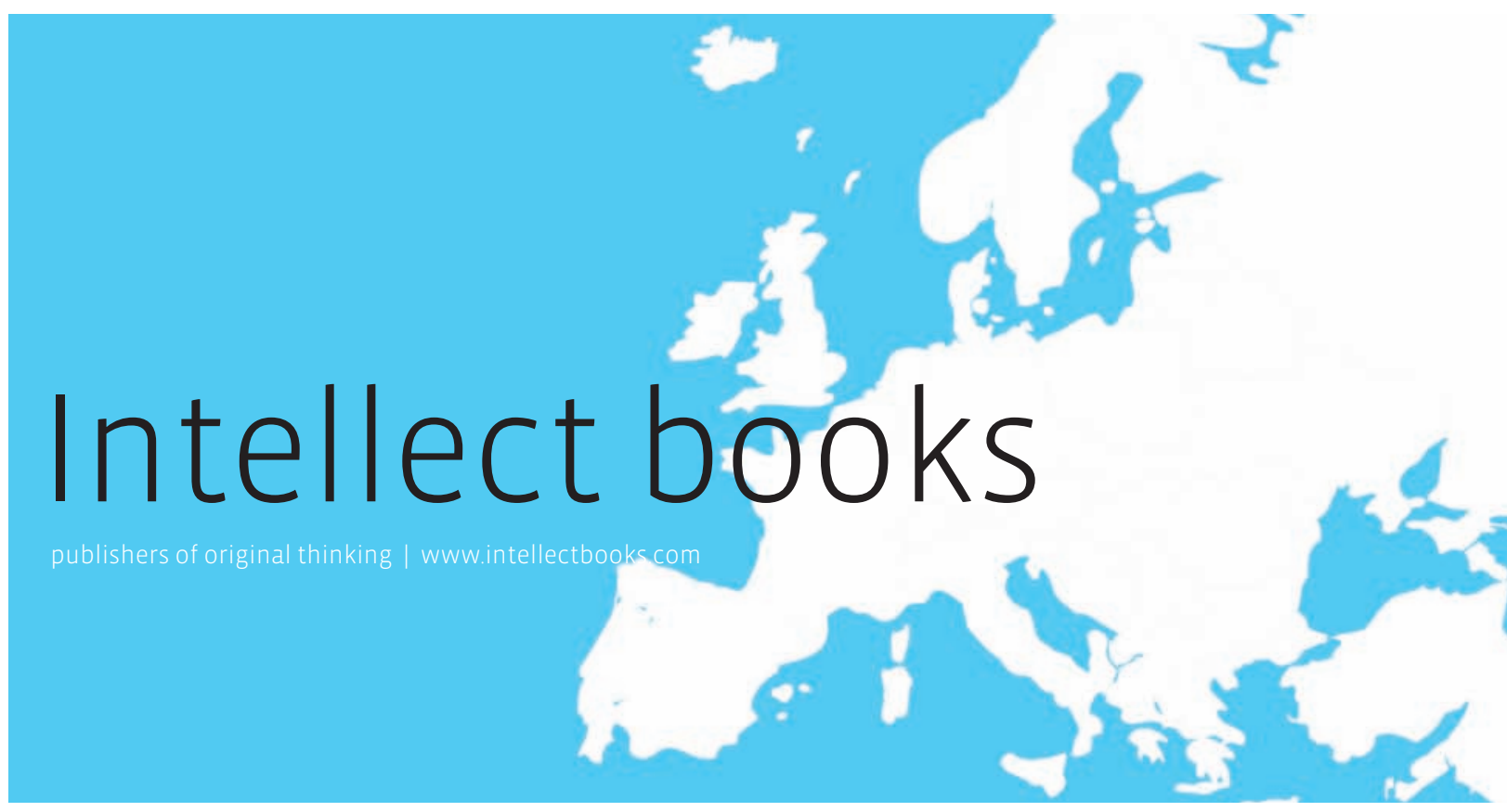

\section{Media in Europe Today}

Edited for The Euromedia Research Group by Josef Trappel, Werner A. Meier, Leen d'Haenens, Jeanette Steemers and Barbara Thomass

With an introduction by Denis McQuail

ISBN 9781841504032

Paperback

UK £19.95 | US \$40

Media in Europe Today provides a comprehensive overview of European media in its current state of transformation. Through a focus on specific European media sectors, it assesses the impact of new technologies across industries and addresses a wide range of practices, strategies and challenges facing European media today. The Euromedia Research Group has more than twenty years of experience in the observation of trends affecting media today, and this book marks the strong continuation of that tradition.

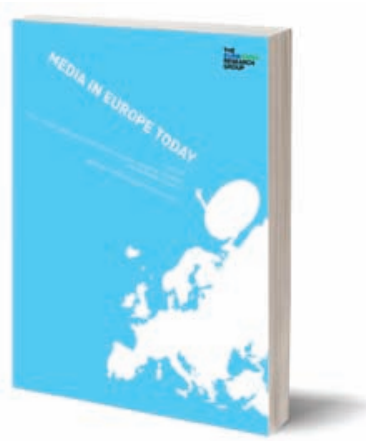

We are here to support your ideas and get them published. To send us your new book or journal proposal, please download a questionnaire from www.intellectbooks.com.

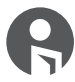

To view our catalogue or order our books and journals visit www.intellectbooks.com Intellect, The Mill, Parnall Road, Fishponds, Bristol, BS163JG.

Tel: +44 (0) 1179589910

Fax:+44 (0) 1179589911 
Copyright of Portuguese Journal of Social Science is the property of Intellect Ltd. and its content may not be copied or emailed to multiple sites or posted to a listserv without the copyright holder's express written permission. However, users may print, download, or email articles for individual use. 